\title{
Contrasting magmatic signatures in the Rairakhol and Koraput alkaline complexes, Eastern Ghats belt, India
}

\author{
S BhatTACHARYA ${ }^{1, *}$ and M BASEI ${ }^{2}$ \\ ${ }^{1}$ Indian Statistical Institute, Kolkata 700 108, India. \\ ${ }^{2}$ Geoscience Institute, São Paulo University, 05508-080, SP Brazil. \\ *e-mail: samar.bhattacharya@gmail.com
}

The relation between alkaline magmatism and tectonism has been a contentious issue, particularly for the Precambrian continental regions. Alkaline complexes at the southwestern margin of Eastern Ghats belt, India, have been interpreted as rift-valley magmatism. However, those complexes occurring in granulite ensemble in the interior segments of the Eastern Ghats belt could not possibly be related to the rift-system, assumed for the western margin of the Eastern Ghats belt. Koraput complex was emplaced in a pull-apart structure, dominated by magmatic fabrics and geochemically similar to a fractionated alkaline complex, compatible with an alkalibasalt series. Rairakhol complex, on the other hand, shows dominantly solid-state deformation fabrics and geochemically similar to a fractionated calc-alkaline suite. Isotopic data for the Koraput complex indicate ca. $917 \mathrm{Ma}$ alkaline magmatism from a depleted mantle source and postcrystalline thermal overprint at ca. $745 \mathrm{Ma}$, also recorded from sheared metapelitic country rocks. The calc-alkaline magmatism of the Rairakhol complex occurred around $938 \mathrm{Ma}$, from an enriched mantle source, closely following Grenvillian granulite facies imprint in the charnockitic country rocks.

\section{Introduction}

While continental flood basalts are more common along successful branches of rift system, alkaline magmatism predominates along failed arms normally preserved within continents (Philpotts 1990). The alkaline province at the southwest margin of the Eastern Ghats granulite terrain is generally interpreted as a rift-valley magmatism, though no in-depth study of the structural setting has yet been undertaken (Leelanandam 1998). Moreover, all these complexes are not of the same age. Except for the modern rift systems such as that of east Africa, the relation between tectonism and magmatism has not been precisely determined. On the other hand, some continental alkaline complexes, such as those of White Mountains in New
Hampshire, Canada, do not appear to be associated with rift valleys, but form elongate belts that may trace the path of moving continent over mantle plume (Foland and Foul 1977).

The alkaline complexes of Rairakhol and Koraput both occur in granulite ensemble and far from the western cratonic margin of the Eastern Ghats belt, India. For such alkaline complexes within the high-grade Eastern Ghats belt, it is difficult to postulate a model of rift-valley magmatism.

In this communication, we present isotopic data for the two complexes and their immediate country rocks in order to reveal the possible link between tectonism and magmatism. Additionally, these data may shed new light on the possible tectonic model for the two alkaline complexes.

Keywords. Alkaline magmatism; granulite ensemble; mantle sources; moving continent. 


\section{Geological setting}

\subsection{Eastern Ghats belt}

The high-grade Eastern Ghats belt along the east coast of India, and bounded by Singhbhum and Bastar cratons to the north and west respectively, is described as a compressional orogen (Bhattacharya 1997; Bhattacharya and Sen 2003). The lithological make-up of this belt could be described in terms of three broad groups, namely, metapelitic granulites, charnockite-enderbite gneisses and associated mafic granulites and migmatitic gneisses. Additionally, a transition zone along significant length of the western margin was also described (Ramakrishnan et al 1998). Anorthosite and alkaline complexes are other important rock types in this high-grade belt. Polyphase deformation and complex, possibly multiple granulite facies records are characteristic of this regional granulite terrane. Recently published Sm-Nd isotopic data suggest a number of crustal domains or provinces with unrelated pre-metamorphic history (Rickers et al 2001). Although dominant and pervasive granulite facies event is of Grenvillian age, older granulite facies imprints as well as later thermal overprints are recorded from several crustal domains (Mezger and Cosca 1999; Bhattacharya et al 2001, 2002, 2003; Bose et al 2008; Simmat and Raith 2008). Moreover, north and south of the Godavari Graben, Eastern Ghats belt is commonly described as separate crustal segments (Mezger and Cosca 1999). One significant difference between the north and south segments relates to the nature of the cratonic margin.

The northern segment is marked by a crustal scale shear zone at the western margin and granite gneisses of the Bastar craton occur in the immediate vicinity (Bhattacharya 2004). South of the Godavari Graben (Ongole domain), on the other hand, Nellore schist belt and Nallamalai fold belt are sandwiched between the Eastern Ghats belt and the Eastern Dharwar craton (Bhattacharya and Saha 2008).

\subsection{Alkaline complexes}

Several alkaline complexes have been reported from the high-grade Eastern Ghats belt (Leelanandam 1998). Many of these complexes occur at or near the southwest margin of the Eastern Ghats belt and commonly described as Prakasam alkaline province, although all are not of the same age. For the Khariar complex, at the northwestern margin of the Eastern Ghats, Upadhyay et al (2006a) described intrusion age of $1480 \pm 17 \mathrm{Ma}$, SHRIMP data from zircon interior. From the
Kunavaram complex of the Prakasam province, Upadhyay and Raith (2006) described an intrusion age of $1384 \pm 63 \mathrm{Ma}$ (the upper intercept) and a metamorphic imprint of $632 \pm 62 \mathrm{Ma}$ (the lower intercept). From Ongole domain, several complexes were dated between 1263 and $1352 \mathrm{Ma}$, by SHRIMP data on zircons (Upadhyay et al 2006b; Upadhyay and Raith 2006; Vijaykumar et al 2007). In a recent publication, Vijaykumar and Leelanandam (2008), suggested that alkaline rocks and carbonatites (ARCs) of the Prakasam province, dated between 1.5 and $1.35 \mathrm{Ga}$, represent rifting along the eastern margin of thickened arc crust. These authors further suggested conversion of ARCs into DARCs (deformed alkaline rocks and carbonatites) either during Grenvillian or Pan-African orogeny. Although, Grenvillian thermal event and related granulite facies metamorphism is dominant in the northern Eastern Ghats belt, southern Eastern Ghats belt, adjoining the Prakasam province, recorded a granulite facies event at 1.6 Ga (Mezger and Cosca 1999; Bhattacharya et al 2010). These data would suggest a post-granulite intrusion for the alkaline complexes of the Prakasam province. On the other hand, some alkaline complexes in the northern Eastern Ghats belt occur in granulite ensemble, far from the western margin. Two such complexes of Koraput and Rairakhol are considered here. Some published ages from these complexes also indicate post-intrusion granulite facies metamorphism (Nanda et al 2008).

\section{Field-setting and petrological background}

Koraput complex was emplaced in a pull-apart structure and flanked by mylonitic shear zones developed in the metapelitic country rocks. This body shows distinct intrusive contact, dominated by magmatic fabrics, no tectonic folds and only occasionally thin shear bands that are interpreted as syntectonic fabric with that in the metapelitic country rocks (Bhattacharya and Kar 2004). Sodic amphibole, acmitic clinopyroxene, annite-rich biotite and sodic plagioclase are typical minerals of an alkaline complex. Bulk chemistry follows a tholeiitic trend with early Feenrichment. Feldspar fractionation is also evident in this complex (Bhattacharya and Kar 2005). High concentration of HFS elements is comparable to that in the within-plate basic sodic magma (Sun and McDonough 1989). However, Gupta et al (2005) described some metamorphic imprints, while Nanda et al (2008) suggested postintrusion granulite facies metamorphism to be 0.70-0.87 Ga, based on U-Pb zircon data. Nanda 
et al (2008) also argued that the host gneisses suffered an earlier granulite facies event. On the other hand, Vijaykumar and Leelanandam (2008) considered the Koraput complex as DARC, a reactivated and exhumed high-grade terrain of the craton.

The Rairakhol complex also occurs in a granulite ensemble and mylonitic shear zones are commonly observed at the margins. Earlier, Panda et al (1993, 1998) considered a rift setting, north of but not far from the Godavari Graben. However, Swain (2005) showed that this complex mostly record solid-state deformation fabrics: gneissic and mineral-defined foliation and folded gneissic foliation and folded boudins. Some mylonitic shear bands are also observed in this complex (Swain 2005). Calcic amphibole and pyroxene, phlogopiterich biotite and calcic plagioclase are the characteristic minerals and on this ground could be described as calc-alkaline rather than alkaline. This is also consistent with a calc-alkaline trend in their bulk composition (Bhattacharya et al 2004). Large positive $\mathrm{Nb}$ anomaly is the characteristic of this complex and could reflect crustal contamination (Condie et al 1987; Saunders et al 1992). Rath et al (1998) and Panda et al (1998) described pegmatoidal and 'younger' intrusives within 'older gneissic members', suggesting more than one episode of nepheline syenite intrusion. The only isotopic data reported from this complex so far, is Rb-Sr whole rock isochron of $1413 \pm 23$ Ma by Sarkar et al (2000).

\section{Isotopic study}

$\mathrm{U}-\mathrm{Pb}$ isotopic analysis of zircons from the two complexes and their immediate country rocks were undertaken to date magma emplacement/crystallization and their relation to the thermal imprints in the country rocks. $\mathrm{Rb}-\mathrm{Sr}$ and $\mathrm{Sm}-\mathrm{Nd}$ isotopic compositions of both felsic and mafic assemblages of the two complexes were determined to understand the nature of the magma sources.

\subsection{Analytical procedure}

The isotopic analyses were performed at the Centre of Research in Geochronology, São Paulo University, using a VG-354 multi-collector mass spectrometer.

For the Rb-Sr analytical work, the measured ratio of ${ }^{87} \mathrm{Sr} /{ }^{86} \mathrm{Sr}$ obtained for NBS 987 standard was $0.710254 \pm 22(2 \sigma)$ and the laboratory blank for the chemical procedure during the period of analysis yielded maximum value of $4 \mathrm{ng}$ for $\mathrm{Sr}$.

For the Sm-Nd analytical work, the measured ratio of ${ }^{143} \mathrm{Nd} /{ }^{144} \mathrm{Nd}$ obtained for La Jolla standard was $0.511857 \pm 0.000046(2 \sigma)$ and the laboratory blanks for the chemical procedure during the period of analysis yielded maximum values of $0.4 \mathrm{ng}$ for $\mathrm{Nd}$ and $0.7 \mathrm{ng}$ for $\mathrm{Sm}$.

For the U-Pb analytical work, the measured ratios of the NBS 982 standard were ${ }^{204} \mathrm{~Pb} /{ }^{206} \mathrm{~Pb}=$ $0.02732 \pm 0.00003 ;{ }^{207} \mathrm{~Pb} /{ }^{206} \mathrm{~Pb}=0.46656 \pm 0.00003$ and ${ }^{208} \mathrm{~Pb} /{ }^{206} \mathrm{~Pb}=0.99783 \pm 0.00005$. The laboratory blanks for the chemical procedure during the period of the analysis yielded maximum values of $15 \mathrm{pg}$ for $\mathrm{Pb}$ and $2 \mathrm{pg}$ for $\mathrm{U}$.

\subsection{Isotopic results}

The U-Pb zircon analytical data for the complexes and their neighbouring country rocks are given in table 1, and whole rock $\mathrm{Rb}-\mathrm{Sr} \& \mathrm{Sm}-\mathrm{Nd}$ data are given in table 2 .

For the Rairakhol complex, U-Pb isotopic data for zircon from nepheline syenite shows an upper intercept age of $946 \pm 6 \mathrm{Ma}$ with MSWD of 7.6, when regressed through origin (figure 1). However, one concordant age of $938.8 \pm 3.1 \mathrm{Ma}$, with MSWD of 1.5, may be taken as the precise magmatic age. It is also important to note that ${ }^{207} \mathrm{~Pb} /{ }^{206} \mathrm{~Pb}$ age of the zircon fractions vary between 931 and $950 \mathrm{Ma}$ (table 1).

The neighbouring charnockitic gneiss records a concordant age of $1006 \pm 4.8 \mathrm{Ma}$, with MSWD of 0.17 (figure 2 and table 1).

Whole rock Rb-Sr and Sm-Nd isotopic data for the Rairakhol complex show negative $f_{\mathrm{Sm}}$ and positive $f_{\mathrm{Rb}}$ values, indicating a source that were enriched in $\mathrm{Rb}$ and depleted in Sm. Also crustal residence age given by $T_{\mathrm{DM}}$ between 1.6 and $1.7 \mathrm{Ga}$. Negative epsilon values (calculated at $938 \mathrm{Ma}$ ) indicate that they were either derived from or assimilated older crustal rocks. Or in other words, their $\mathrm{Sm} / \mathrm{Nd}$ had been lowered originally when they were separated from mantle. Initial $\mathrm{Sr}$ and $\mathrm{Nd}$ values calculated at $938 \mathrm{Ma}$ are 0.70820 and 0.70902 , and 0.511209 and 0.511142 , respectively. These values indicate an enriched composition of their mantle source.

For the Koraput complex discordia diagram for zircon from nepheline syenite shows an upper intercept age $917 \mathrm{Ma}$ and lower intercept age of $745 \mathrm{Ma}$, with MSWD of 0.093 (figure 3). Here the ${ }^{207} \mathrm{~Pb} /{ }^{206} \mathrm{~Pb}$ age of zircon fractions vary between 774 and $820 \mathrm{Ma}$ and if these are considered as the minimum crystallization age, the 917 Ma upper intercept age may be taken as the intrusion age, while the lower intercept age of $745 \mathrm{Ma}$ may be considered as a later thermal overprint. In fact this age is also recorded from U-Pb isotopic data of zircons of the metapelitic country rocks around the Koraput complex (figure 4). Here lower intercept age of $746 \mathrm{Ma}$ and upper intercept age of $2244 \mathrm{Ma}$ 
Table 1. U-Pb isotopic data for zircons from alkaline complexes and country rocks.

\begin{tabular}{|c|c|c|c|c|c|c|c|}
\hline Sample & $\begin{array}{c}\mathrm{Pb} \\
(\mathrm{ppm})\end{array}$ & $\begin{array}{c}\mathrm{U} \\
(\mathrm{ppm})\end{array}$ & ${ }^{206} \mathrm{~Pb} /{ }^{204} \mathrm{~Pb}$ & ${ }^{206} \mathrm{~Pb} /{ }^{238} \mathrm{U}$ & ${ }^{207} \mathrm{~Pb} /{ }^{235} \mathrm{U}$ & ${ }^{207} \mathrm{~Pb} /{ }^{206} \mathrm{~Pb}$ & $\begin{array}{c}{ }^{207} \mathrm{~Pb} /{ }^{206} \mathrm{~Pb} \\
(\mathrm{Ma})\end{array}$ \\
\hline \multicolumn{8}{|c|}{ Nepheline syenite, Rairakhol complex } \\
\hline A & 89.0 & 595.4 & 1987.1 & $0.157282 \pm 22$ & $1.52401 \pm 35$ & $0.070276 \pm 262$ & 936 \\
\hline $\mathrm{C}$ & 80.9 & 531.8 & 1264.3 & $0.15675 \pm 9$ & $1.51858 \pm 132$ & $0.070264 \pm 363$ & 936 \\
\hline B & 80.4 & 529.8 & 1190.0 & $0.157755 \pm 24$ & $1.53857 \pm 209$ & $0.070735 \pm 291$ & 950 \\
\hline $\mathrm{D}$ & 118.8 & 778.3 & 2516.6 & $0.15876 \pm 7$ & $1.54427 \pm 127$ & $0.070547 \pm 187$ & 944 \\
\hline $\mathrm{E}$ & 114.3 & 794.0 & 1801.1 & $0.151283 \pm 76$ & $1.4738 \pm 65$ & $0.070655 \pm 218$ & 947 \\
\hline $\mathrm{F}$ & 98.8 & 681.0 & 1673.7 & $0.150573 \pm 43$ & $1.4555 \pm 69$ & $0.070107 \pm 275$ & 931 \\
\hline RAS49 & \multicolumn{7}{|c|}{ Charnockitic gneiss, Rairakhol } \\
\hline A & 75.2 & 425.5 & 868.4 & $0.169355 \pm 34$ & $1.6981 \pm 146$ & $0.072722 \pm 241$ & 1006 \\
\hline B & 109.7 & 669.0 & 3104.0 & $0.172511 \pm 23$ & $1.76616 \pm 158$ & $0.074253 \pm 421$ & 1048 \\
\hline $\mathrm{C}$ & 85.5 & 490.1 & 512.7 & $0.174465 \pm 15$ & $1.78434 \pm 237$ & $0.074177 \pm 288$ & 1046 \\
\hline K68 & \multicolumn{7}{|c|}{ Nepheline syenite, Koraput complex } \\
\hline A & 15.4 & 82.6 & 1303 & $0.133737 \pm 18$ & $1.224810 \pm 322$ & $0.066423 \pm 175$ & 820 \\
\hline B & 8.0 & 41.0 & 361 & $0.127960 \pm 22$ & $1.1488 \pm 243$ & $0.065114 \pm 163$ & 778 \\
\hline $\mathrm{C}$ & 13.2 & 84.1 & 617 & $0.126671 \pm 97$ & $1.135030 \pm 164$ & $0.064987 \pm 298$ & 774 \\
\hline $\mathrm{D}$ & 10.4 & 50.2 & 303 & $0.128562 \pm 49$ & $1.166410 \pm 259$ & $0.065802 \pm 247$ & 800 \\
\hline KH6 & \multicolumn{7}{|c|}{ Metapelitic granulite, Koraput } \\
\hline A & 46.5 & 340.5 & 869 & $0.135209 \pm 49$ & $1.263590 \pm 146$ & $0.067780 \pm 238$ & 862 \\
\hline B & 43.9 & 269.7 & 3170 & $0.155010 \pm 113$ & $1.858450 \pm 248$ & $0.086954 \pm 152$ & 1360 \\
\hline $\mathrm{C}$ & 36.1 & 270.9 & 1509 & $0.134697 \pm 67$ & $1.368650 \pm 348$ & $0.073694 \pm 244$ & 1033 \\
\hline $\mathrm{D}$ & 51.2 & 398.1 & 3113 & $0.129969 \pm 28$ & $1.282470 \pm 224$ & $0.071566 \pm 183$ & 974 \\
\hline $\mathrm{E}$ & 36.7 & 272.4 & 1791 & $0.135615 \pm 145$ & $1.347160 \pm 349$ & $0.072046 \pm 257$ & 987 \\
\hline
\end{tabular}

are recorded with MSWD of 3.3. The upper intercept age of $2244 \mathrm{Ma}$, could define protolith age of the khondalites; incidentally, similar protolith ages for the paragneisses of the Eastern Ghats belt, by $\mathrm{Sm}-\mathrm{Nd}$ systematic have been described earlier (Rickers et al 2001).

Whole rock $\mathrm{Rb}-\mathrm{Sr}$ and $\mathrm{Sm}-\mathrm{Nd}$ isotopic data for the Koraput complex show negative $f_{\mathrm{Sm}}$ and positive $f_{\mathrm{Rb}}$ values, indicating a source that were enriched in $\mathrm{Rb}$ and depleted in $\mathrm{Sm}$. Also mantle derivation age given by $T_{\mathrm{DM}}$ is ca. $1.0 \mathrm{Ga}$. Positive epsilon values (calculated at $917 \mathrm{Ma}$ ) indicate that the rocks were derived from residual solids in the mantle reservoir, after magma had been withdrawn at an earlier time. Initial Sr and $\mathrm{Nd}$ values calculated at $917 \mathrm{Ma}$ are 0.70252 and 0.70306 , and 0.511698 and 0.511652 , respectively. These values further indicate a depleted mantle as their source. However, alkali enrichment in this complex is apparently contrary to the depleted mantle source, as indicated by the initial $\mathrm{Sr}$ and $\mathrm{Nd}$ values as also the positive epsilon values. But this alkali enrichment can be explained in terms of a later thermal imprint at $\sim 745 \mathrm{Ma}$ (lower intercept in $\mathrm{U}-\mathrm{Pb}$ discordia (figure 3$)$ ).

\section{Discussion}

Both the Rairakhol and Koraput complexes occur in granulite ensemble and far from the cratonic margin. The alkaline complexes of the Prakasam province occur in a plate margin setting and hence amenable to explanation by rift-valley magmatism. Vijaykumar and Leelanandam (2008) proposed that ARCs of the Prakasam province, aged between 1.5 and $1.35 \mathrm{Ga}$ represent rifting along eastern margin of the thickened arc crust; while conversion to the DARCs may be related to either the Grenvillian or Pan-African orogeny. Two complexes of the present study occur in an intra-plate setting and hence not easily explainable by riftvalley magmatism. Incidentally, high concentration of HFS elements in the Koraput complex is also compatible with the within-plate basic sodic magma (Sun and McDonough 1989). Again the isotopic data for these two complexes indicate broadly syntectonic intrusion with granulite facies metamorphism (dominant Grenvillian in the northern Eastern Ghats belt), in a compressional setting. Hence these are unlikely the older ARCs later converted to DARCs, as envisaged by Vijaykumar and Leelanandam (2008). For such continental plutonic 

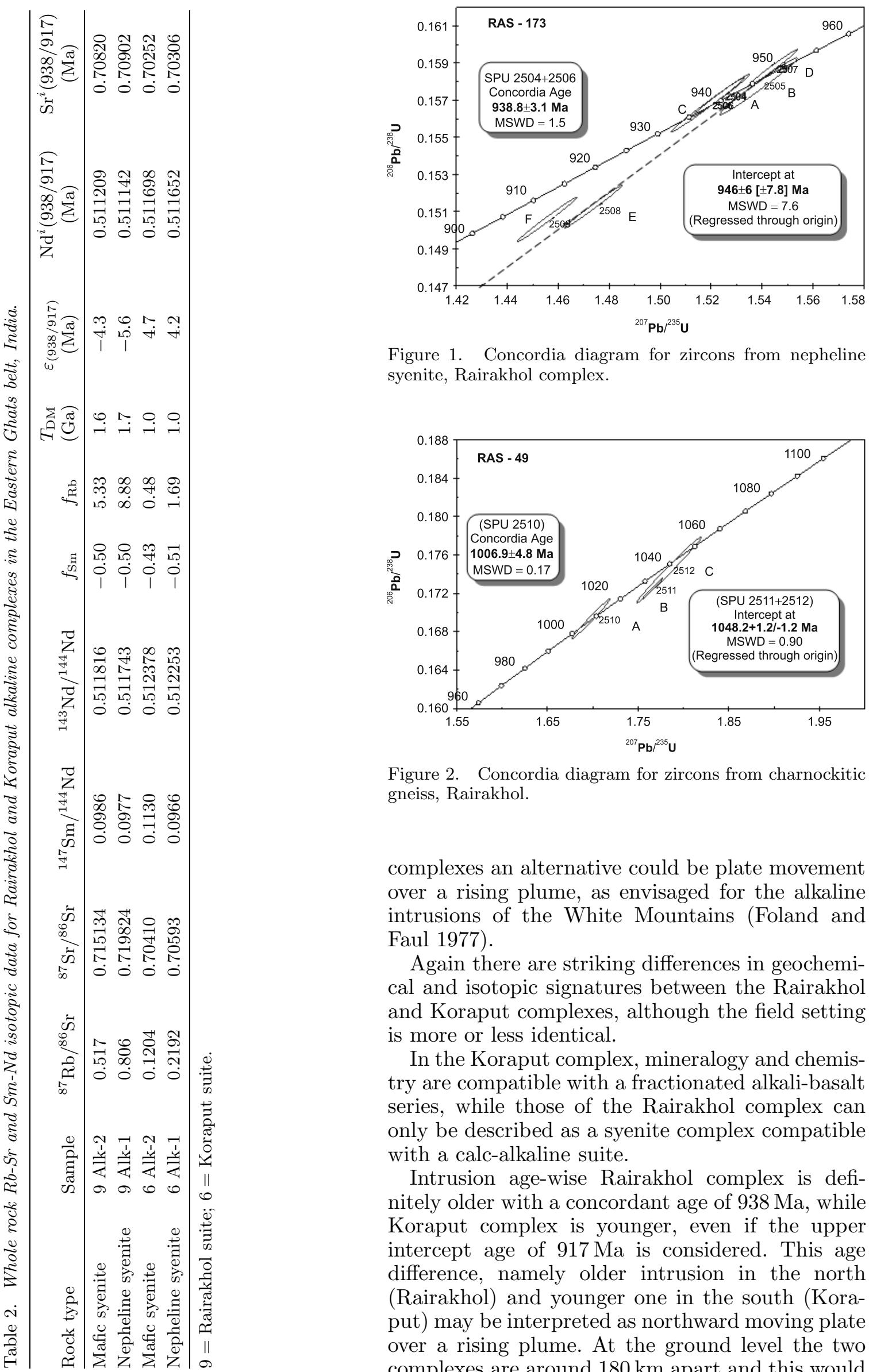

Figure 1. Concordia diagram for zircons from nepheline syenite, Rairakhol complex.

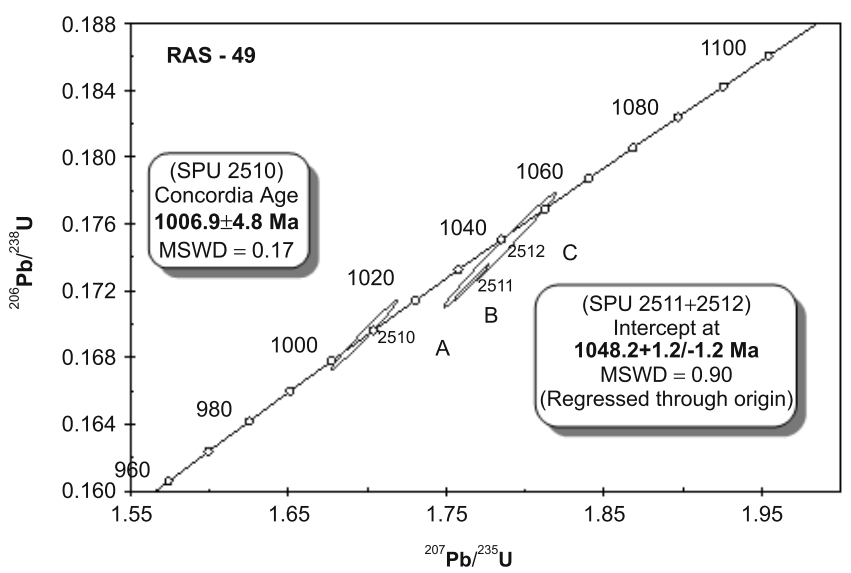

Figure 2. Concordia diagram for zircons from charnockitic gneiss, Rairakhol.

complexes an alternative could be plate movement over a rising plume, as envisaged for the alkaline intrusions of the White Mountains (Foland and Faul 1977).

Again there are striking differences in geochemical and isotopic signatures between the Rairakhol and Koraput complexes, although the field setting is more or less identical.

In the Koraput complex, mineralogy and chemistry are compatible with a fractionated alkali-basalt series, while those of the Rairakhol complex can only be described as a syenite complex compatible with a calc-alkaline suite.

Intrusion age-wise Rairakhol complex is definitely older with a concordant age of $938 \mathrm{Ma}$, while Koraput complex is younger, even if the upper intercept age of $917 \mathrm{Ma}$ is considered. This age difference, namely older intrusion in the north (Rairakhol) and younger one in the south (Koraput) may be interpreted as northward moving plate over a rising plume. At the ground level the two complexes are around $180 \mathrm{~km}$ apart and this would 


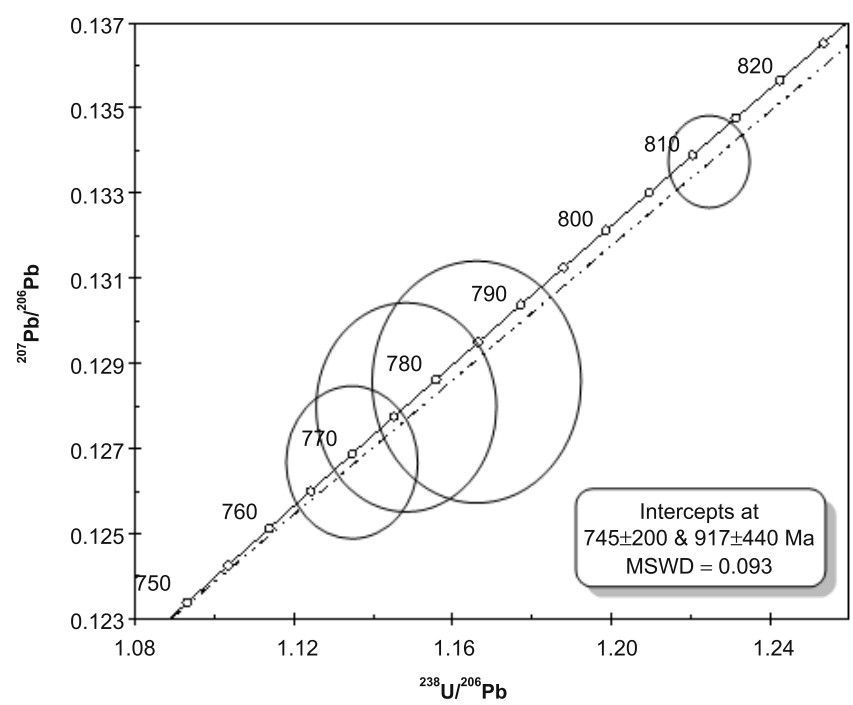

Figure 3. Concordia diagram for zircons from nepheline syenite, Koraput suite.

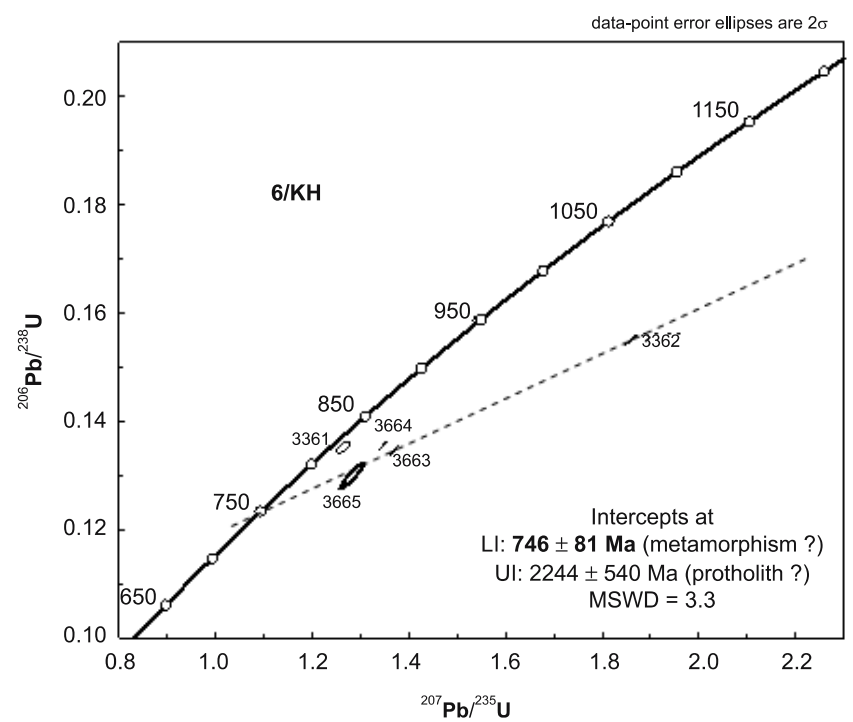

Figure 4. Concordia diagram for zircons from metapelitic granulite, Koraput.

indicate horizontal movement of the continental plate at $\sim 9 \mathrm{~mm}$ per year.

$\mathrm{Sr}-\mathrm{Nd}$ isotopic signatures in the two complexes are also distinct. While the Koraput complex has depleted mantle composition as its source, the Rairakhol complex has enriched mantle composition as its source. For the Koraput complex, postintrusion thermal imprint, as in this presentation as also by others (Gupta et al 2005; Nanda et al 2008) can explain the apparent contradiction between a depleted mantle source and alkali enriched compositions of the rocks.

It was suggested in an earlier paper that Rairakhol complex was the result of intra-crustal melting, on the evidence of negative epsilon values (Bhattacharya et al 2004). The significant difference between intrusion age (938 Ma) and crustal residence ages (1.6-1.7 Ga) of the Rairakhol complex, apparently supports that contention. However, it is difficult to postulate melting of crustal rocks to produce nepheline normative magma, unless alkali enrichment can be demonstrated as a post-intrusion phenomenon. Although, solid-state deformation fabrics dominate in this complex, no metamorphic changes or postintrusion thermal imprints have been recorded in this complex, unlike that in the Koraput complex. Two other alternative interpretations may also be considered. Parental basic magma may have resided in a lower crustal chamber for a long period, until fractionation lowered their density to the point that the largely felsic magma could buoyantly rise through the crust (Philpotts 1990). However, for the Rairakhol complex this period is appreciably long of the order of $500 \mathrm{Ma}$, and hence an unlikely proposition. In the other alternative interpretation, assimilation of older crustal rocks may be responsible for the negative epsilon values at the time of intrusion. A long crustal residence, in that case, may represent the older crustal rocks in this interpretation. Incidentally, large positive $\mathrm{Nb}$ anomaly, reported earlier (Bhattacharya et al 2004), also suggests crustal contamination. Thus our favoured interpretation for the Rairakhol complex is assimilation of older crustal rocks during intrusion.

In relation to the granulite facies thermal imprints, dominated by the Grenvillian event $(1.1$ to $0.9 \mathrm{Ga})$, both the complexes are broadly syntectonic, although, later thermal imprints $\sim 745 \mathrm{Ma}$ are recorded in the Koraput complex and sheared metapelitic country rocks. Around $800 \mathrm{Ma}$ thermal overprints are recorded from several segments in some recent publications (Simmat and Raith 2008), as also some unpublished data of monazites with the authors.

\section{Acknowledgements}

Isotopic analytical work was undertaken at the Geochronological Research Centre, University of São Paulo, Brazil under a collaborative Research Project C-91 and SB acknowledges support from the Centre. Indian Statistical Institute, Kolkata is acknowledged for providing infrastructural facilities.

\section{References}

Bhattacharya S 1997 Evolution of the Eastern Ghats granulite belt of India in a compressional tectonic regime and juxtaposition against Iron Ore Craton of Singhbhum by oblique collision-transpression; Proc. Indian Acad. Sci. (Earth Planet. Sci.) 106 65-75. 
Bhattacharya S, Kar R, Misra S and Teixeira W 2001 Early Archaean continental crust in the Eastern Ghats granulite belt, India: Isotopic evidence from a charnockite suite; Geol. Mag. 138 609-618.

Bhattacharya S, Deomurari D P and Teixeira W 2002 Grenvillian thermal event and remnant charnockite: Isotopic evidence from the Chilka Lake granulite-migmatite suite in the Eastern Ghats belt, India; Proc. Indian Acad. Sci. (Earth Planet. Sci.). 111 391-399.

Bhattacharya S, Kar R, Teixeira W and Basei M 2003 Hightemperature crustal anatexis in a clockwise P-T-t path: Isotopic evidence from a granulite-granitoid suite in the Eastern Ghats belt, India; J. Geol. Soc. London 160 39-46.

Bhattacharya S and Sen S K 2003 Thermotectonic modeling of convergent orogens: Involvement of mantle and implications for P-T-t paths; GEOS 14 7-12.

Bhattacharya S 2004 High-temperature crustal scale shear zone at the western margin of the Eastern Ghats granulite belt, India: Implications for rapid exhumation; J. Asian Earth Sci. 24 281-290.

Bhattacharya S and Kar R 2004 Alkaline intrusion in a granulite ensemble in the Eastern Ghats belt, India: Shear zone pathway and a pull-apart structure; Proc. Indian Acad. Sci. (Earth Planet. Sci.) 113 37-48.

Bhattacharya S, Swain A K and Teixeira W 2004 Crustal source for a syenite complex in the high-grade Eastern Ghats belt, India: Sm-Nd isotopic evidence; Gond. Res. $7627-629$.

Bhattacharya S and Kar R 2005 Petrological and geochemical constraints on the evolution of the alkaline complex of Koraput in the Eastern Ghats granulite belt, India; Gond. Res. 8 596-602.

Bhattacharya S and Saha D 2008 Geo-traverse across the Eastern Ghats belt, adjoining fold-and-thrust belt and the proterozoic Cuddapah Basin, South India; Field guide, Indian Statistical Institute, 1-48.

Bhattacharya S, Das P, Chaudhary A K and Saw A K 2010 Mafic granulite xenoliths in the Eastern Ghats Granulite belt: Implications for lower crustal processes in the southeastern Indian Peninsula. India J. Geol. (in press).

Bose S, Dunkley D J and Arima M 2008 Zircon U-Pb SHRIMP ages from Eastern Ghats belt and their implication on the Indo-antarctic correlation; Abstract AGU Fall Meeting.

Condie K C, Bobrow D J and Card K D 1987 Geochemistry of Precambrian mafic dykes from southern Superior Province of the Canadian Shield; In: Mafic dyke swarms, (eds) Halls H C and Fahrig W F, Geol. Assoc. Canada Spec. Paper 34 95-108.

Foland K A and Faul H 1977 Ages of White Mountain intrusives - New Hampshire, Vermont, and Maine; Am. J. Sci. 277 888-904.

Gupta S, Nanda J, Mukherjee S K and Santra M 2005 Alkaline magmatism versus collision tectonics in the Eastern Ghats belt, India: Constraints from structural studies in the Koraput complex; Gond. Res. 8 403-419.

Leelanandam C 1998 Alkaline magmatism in the Eastern Ghats belt - A critique; Geol. Surv. India Spec. Publ. 44 170-179.

Mezger K and Cosca M A 1999 The thermal history of the Eastern Ghats belt (India) as revealed by U-Pb and ${ }^{40} \mathrm{Ar} /{ }^{39} \mathrm{Ar}$ dating of metamorphic and magmatic minerals: Implications for the SWEAT correlation; Precamb. Res. 94 251-271.
Nanda J, Gupta S and Dobmeier C 2008 Metamorphism of the Koraput Alkaline Complex, Eastern Ghats Province, India - Evidence for reworking of a granulite terrane; Precamb. Res. 165 153-168.

Panda P K, Patra P C, Patra R N and Nanda J 1993 Nepheline syenite from Rairakhol, Sambalpur district, Orissa; India J. Geol. 41 144-151.

Panda P K, Patra P C and Nanda J K 1998 Petrochemistry of the alkaline rocks of Rairakhol-Kankarakhol belt, Sambalpur and Deogarh districts, Orissa; Geol. Surv. India Spec. Publ. 44 307-314.

Philpotts A R 1990 Principles of igneous and metamorphic petrology (New Jersey: Prentice Hall).

Ramakrishnan M, Nanda J K and Augustine P F 1998 Geological evolution of the Proterozoic Eastern Ghats mobile belt; Geol. Surv. India Spec. Publ. 44 1-21.

Rath S C, Sahoo K C and Satpathy U N 1998 The Kankarkhol-Lodhajhari alkaline complex at the margin of Eastern Ghats, Deogarh district, Orissa, India; Int. Seminar on Precambrian Crust in Eastern and Central India, Bhubaneswar, Abstract, 109-112.

Rickers K, Mezger K and Raith M 2001 Evolution of the continental crust in the Proterozoic Eastern Ghats belt, India and new constraints for Rodinia reconstruction: Implications from $\mathrm{Sm}-\mathrm{Nd}, \mathrm{Rb}-\mathrm{Sr}$ and $\mathrm{Pb}-\mathrm{Pb}$ isotopes; Precamb. Res. 112 183-210.

Sarkar A, Pati U C, Panda P K, Kundu H K and Ghosh S 2000 Late-Archaean charnockitic rocks from the northern marginal zones of the Eastern Ghats belt: A geochronological study; Geol. Surv. Spec. Publ. 57 171-179.

Saunders A D, Storey M, Kent R and Norry M J 1992 Consequences of plum-lithosphere interactions; In: Magmatism and the Causes of Continental Break-up (eds) Storey B C, Alabaster T and Pankhurst R J, Geol. Soc. London Spec. Publ. 68 41-60.

Simmat R and Raith M 2008 U-Th-Pb monazite geochronology of the Eastern Belt, India: Timing and spatial disposition of polymetamorphism; Precamb. Res. 162 16-39.

Sun S S and McDonough W F 1989 Chemical and isotopic systematics of oceanic basalts: Implications for mantle compositional and processes; Geol. Soc. London Spec. Publ. 42 313-345.

Swain A K 2005 Structural setting of the Rairakhol alkaline complex, Eastern Ghats, India; India J. Geol. 77 33-44.

Upadhyay D, Raith M M, Mezger K and Hammerschmidt K 2006a Mesoproterozoic rift-related alkaline magmatism at Elchuru, Prakasam Alkaline Province, SE India; Lithos 89 447-477.

Upadhyay D, Raith M M, Mezger K, Bhattacharya A and Kinny P D 2006b Mesoproterozoic rifting and PanAfrican continental collision in SE India: Evidence from Khariar alkaline complex; Contrib. Mineral. Petrol. 151 434-456.

Upadhyay D and Raith M M 2006 Intrusion age, geochemistry and metamorphic conditions of a quartzmonzosyenite intrusion at the craton-Eastern Ghats Belt contact near Jojuru, India; Gond. Res. 10 267-276.

Vijaykumar K, Frost C D, Frost B R and Chamberlain K R 2007 The Chimakurti, Errakonda and Uppalapadu plutons, Eastern Ghats belt, India: An unusual association of tholeiitic and alkaline magmatism; Lithos $\mathbf{9 7}$ $30-57$.

Vijay Kumar K and Leelanandam C 2008 Evolution of the Eastern Ghats belt, India: A plate tectonic perspective; J. Geol. Soc. India 72 720-749. 